\title{
OCENA STABILNOŚCI DOCHODÓW PUBLICZNYCH NA PRZYKŁADZIE ZASOBÓW WŁASNYCH UNII EUROPEJSKIEJ W LATACH 2000-2010
}

\section{WSTĘP}

W literaturze przedmiotu wskazuje się, że dochody publiczne powinny być stabilne zarówno w krótkim, jak i długim okresie. Wówczas zapewnione są odpowiednie środki na realizację zadań publicznych, a także utrzymane jest szeroko rozumiane bezpieczeństwo finansów publicznych ${ }^{1}$. Pojęcie stabilności dochodów publicznych nie zostało jednak jednoznacznie zdefiniowane. W konsekwencji zjawisko to jest różnie mierzone, a także wskazuje się na różne przyczyny i metody przeciwdziałania niestabilności dochodów publicznych. Celem artykułu jest przybliżenie pojęcia stabilności dochodów publicznych oraz zaproponowanie metody pomiaru tej stabilności za pomoca tzw. ws półczynnika zmienności. Badanie stabilności zostanie przeprowadzone na przykładzie systemu zasobów własnych Unii Europejskiej obowiąującego w latach 2000-2010.

\section{POJĘCIE I MIARA STABILNOŚCI DOCHODÓW PUBLICZNYCH}

Zagadnienie stabilności dochodów publicznych rozpatrywane jest w różnych ujęciach. Stanisław Owsiak posługuje się pojęciem „stabilności źródeł finansowania" i rozpatruje je w kontekście wieloletniego planowania zadań publicznych zarówno na szczeblu państwa, jak i jednostek samorządu terytorialnego ${ }^{2}$. Według tego autora stabilne źródła finansowania to takie, które zapewniają zdolność państwa do regulowania jego zobowiązań, a przede wszystkim do zasilania pieniędzmi podmiotów realizujących zadania publiczne. W konsekwencji istnienie takiej stabilności finansowej gwarantuje uniknięcie kryzysu gospodarczego. Owsiak wskazuje również, że funkcję stabilizująca mogą pełnić zarówno dochody własne, jak i pożyczki, w zależności od obowiązującego dogmatu równowagi budżetowej. Z kolei niestabilności źródeł

1 S. Owsiak, Stabilność systemu zasilania finansowego a nowatorskie zarzadzanie podmiotami publicznymi w warunkach kryzysu, w: idem (red.), Nowe zarzadzanie finansami publicznymi w warunkach kryzysu, Polskie Wydawnictwo Ekonomiczne, Warszawa 2011, s. 24.

2 Ibidem, s. 30 i 31. 
finansowania sprzyjają nieodpowiednie zmiany w przepisach regulujących dochody budżetowe oraz zmiany cyklu koniunkturalnego. W celu zapobiegania wahaniom dochodów publicznych autor proponuje tworzenie rezerw finansowych w okresach wzrostu gospodarczego, które maja pokrywać niedobory środków w okresach recesji.

William F. Fox rozpatruje stabilność różnych dochodów publicznych na szczeblu stanów USA w połączeniu z wydajnością tych dochodów i realizacja zadań publicznych w długim okresie ${ }^{3}$. Według tego autora dochody budżetowe powinny być wydajne w długim okresie, a warunkiem tej wydajności jest ich stabilność. Długi okres analizy wynika z faktu, że wykonywanie większości zadań publicznych jest $\mathrm{w}$ zasadzie procesem ciagłym podzielonym na lata, wynikającym z odpowiedzialności politycznej, a nie jednorazowym przedsięwzięciem odbywającym się $\mathrm{w}$ określonym czasie. Zapewnienie wydajności i stabilności finansowania w długim okresie jest więc zadaniem zdecydowanie ważniejszym i trudniejszym niż dbanie o równowagę krótkookresowa. Przez wydajność dochodów autor rozumie zapewnienie odpowiednich środków na realizacje zadań publicznych, a przez stabilność - dostosowanie tych dochodów do kosztów zadań publicznych, przy czym te ostatnie powinny wynikać z rozmiarów gospodarki. $\mathrm{W}$ opinii autora rozmiary zadań publicznych $\mathrm{w}$ poszczególnych stanach powinny być wyrażone procentowym udziałem w gospodarce.

Iain Begg i Nigel Grimwade badają stabilność potencjalnych zasobów własnych Unii Europejskiej, przy obowiązującej zasadzie zrównoważonego budżetu ogólnego ${ }^{4}$. Według tych autorów stabilne dochody to takie, które nie poddaja się istotnym wahaniom koniunkturalnym, a więc bez względu na te wahania zawsze będą charakteryzować się określoną wydajnością. Autorzy wskazują że stabilność dochodów miałaby mniejsze znaczenie, gdyby budżet ogólny UE mógł być uchwalany z deficytem lub nadwyżką. Wówczas ewentualne niedobory środków ze źródeł zasobów własnych mogą być uzupełniane pożyczkami.

W podobny sposób stabilność potencjalnych zasobów własnych UE przedstawiają Philippe Cattoir i Elżbieta Kawecka-Wyrzykowska, a także Komisja Europejska. Pierwszy z autorów oraz Komisja Europejska dokonuja jakościowej oceny potencjalnych zasobów własnych UE według zestawu określonych kryteriów, w tym stabilności w długim okresie ${ }^{5}$. Z kolei Kawecka-Wyrzykowska według tego samego zestawu kryteriów ocenia jedna z propozycji nowego VAT UE na tle innych potencjalnych źródeł dochodów ${ }^{6}$. Nowa koncepcja unijnego VAT zakłada, że w każdym państwie członkowskim UE część dochodów z VAT byłaby kierowana nie do budżetu krajowego, a do budżetu unijnego. Stawka VAT (np. w wysokości 1\%) byłaby obliczana od tej samej podstawy opodatkowania, co stawka krajowa, przy czym byłaby ustalona w ramach obecnie obo-

${ }^{3}$ W. F. Fox, The Ongoing Evolution of State Revenue System, „Marquette Law Review” 2004, nr 88/19.

${ }^{4}$ I. Begg, N. Grimwade, Paying for Europe, Sheffield Academic Press, Sheffield 1998, s. 102.

${ }^{5}$ P. Cattoir, Tax-Based UE Own Resource: An Assessment, European Commission Taxation Papers, Working Paper 2004, No 1, April.

${ }^{6}$ E. Kawecka-Wyrzykowska, VAT jako nowe źródto dochodu budżetu Unii Europejskiej, w: eadem (red.), Budżet dla Unii Europejskiej po 2013 roku. Implikacje dla Polski, Szkoła Główna Handlowa w Warszawie, Warszawa 2008, s. 112. 
wiąujących krajowych stawek VAT. W konsekwencji podatnicy nie ponosiliby dodatkowego ciężaru podatkowego na rzecz unijnego budżetu ${ }^{7}$. Za miarę stabilności tego źródła dochodów autorka przyjmuje korelację wpływów z niego do PKB per capita. Im większa jest ta korelacja, tym podatek będzie bardziej stabilny i odwrotnie. Autorka posługuje się terminami stabilności, częściowej stabilności i niskiej stabilności. Nowy VAT UE został oceniony jako stabilny, gdyż korelacja jego wpływów z PKB wyniosła 93,6\%, akcyzę na paliwa oraz tytoń i alkohol charakteryzuje częściowa stabilność, gdyż korelacja z PKB wyniosła odpowiednio 81,3 oraz $66,5 \%$, a podatek od zysków przedsiębiorstw charakteryzuje niska stabilność, gdyż korelacja z PKB wyniosła $42,3 \%{ }^{8}$.

Ze wskazanej literatury wynika, że stabilność dochodów publicznych rozpatruje się przede wszystkim w powiązaniu z koniunktura gospodarcza, przy czym funkcjonuja dwa odmienne podejścia. W pierwszym podejściu dochody publiczne traktuje się jako stabilne, gdy zapewniaja budżetowi stałe i wystarczające środki bez względu na wahania koniunkturalne (Owsiak, Begg i Grimwade, Cattoir), natomiast w drugim - gdy sa z tymi wahaniami skorelowane (Fox, Kawecka-Wyrzykowska). Kawecka-Wyrzykowska zaproponowała przy tym sposób pomiaru tej stabilności za pomocą współczynnika korelacji.

Autorzy niniejszego opracowania proponują odmienne i bardziej uniwersalne podejście do badania stabilności dochodów publicznych. W artykule stabilność ta będzie rozpatrywana wyłącznie w kontekście wahań dochodów bez powiązania z wydajnością fiskalna, obowiąującymi zasadami budżetowymi, czasem i cyklem koniunkturalnym. Dochody z danego źródła będą tym bardziej stabilne w danym czasie, im mniejszymi wahaniami będą się charakteryzować i odwrotnie. Stopień wahań zostanie oszacowany przy zastosowaniu tzw. współczynnika zmienności, a ocena tej zmienności zostanie dokonana na podstawie ustalonych przedziałów tych wahań. Zastosowanie tej metody umożliwia zbadanie i porównanie stabilności poszczególnych źródeł dochodów lub ich całych systemów na różnych szczeblach władzy publicznej.

\section{SYSTEM ZASOBÓW WŁASNYCH UE W LATACH 2000-2010}

W perspektywie finansowej na lata 2000-2006 budżet UE zasilały tzw. zasoby własne oraz dochody pozostałe. W pierwszej grupie znajdowały się tzw. dochody tradycyjne (cła rolne, opłaty cukrowe oraz cła handlowe), wpłaty z tytułu VAT oraz wpłaty z tytułu DNB ${ }^{9}$. Zasoby tradycyjne zasilają unijny budżet od 1971 r. Cła pełniły funkcję ochronna. Były nakładane na produkty importowane spoza Unii w celu wyrównania poziomu cen tych produktów z produktami wytworzonymi na terenie Unii. Do końca 2008 r. cła rolne i cła handlowe funkcjonowały na odmiennych zasadach. Te pierwsze były nakładane

\footnotetext{
${ }^{7}$ Ibidem, s. 110 i 111.

${ }^{8}$ E. Kawecka-Wyrzykowska, VAT jako źródto dochodu budżetu europejskiego (VAT as an EU budget resource), A study prepared at the request of the Office for European Integration in Poland in the framework of consultations on the EU Budget Reform), Warszawa, styczen 2008, s. 28.

${ }^{9}$ Council Decision of 29 September 2000 on the system of the European Communities' own resources, OJ L 253 ze zm.
} 
na produkty rolne objęte tzw. wspólną polityką rolną. Wysokość i zasady ich nakładania były zróżnicowane w przekroju tzw. wspólnych organizacji rynków odpowiadających poszczególnym rodzajom produktów lub ich grupom (np. rynek wina, cukru, mleka i przetworów mlecznych itd.). W badanym okresie funkcjonowało 21 takich rynków. Z kolei cła handlowe były nakładane na podstawie tzw. wspólnej taryfy celnej oraz odrębnych zasad dotyczacych towarów Europejskiej Wspólnoty Węgla i Stali.

Opłaty cukrowe były nakładane na produkcję cukru, izoglukozy i inuliny. Opłaty te miały charakter celowy. Były one instrumentem regulowania podaży produktów cukrowych na wewnętrznym rynku. Środki uzyskane z tych opłat były przeznaczane na dofinansowanie eksportu produktów oraz na dopłaty do cukru wykorzystywanego w przemyśle chemicznym i dopłaty do jego przechowywania. Występowało wiele rodzajów opłat cukrowych. Najważniejszą była opłata produkcyjna pobierana w euro od tony wytworzonego produktu.

Państwa członkowskie były zobowiązane do zebrania i odprowadzenia zasobów tradycyjnych do unijnego budżetu i z tego tytułu mogły od zebranych środków potracić koszty administracyjne.

Kolejnym zasobem własnym Unii były wpłaty państw członkowskich z tytułu VAT. Podatek ten występuje we wszystkich państwach członkowskich i jest zharmonizowany. Obliczenie należnych wpłat do unijnego budżetu wymagało określenia przez każde państwo odrębnej podstawy oraz zastosowania ujednoliconej stawki. W badanym okresie podstawa obliczana była tzw. metodą dochodowa, tj. na podstawie dochodów budżetowych z VAT państw członkowskich. W celu złagodzenia negatywnych efektów regresywnego charakteru VAT dla każdego państwa członkowskiego ograniczono podstawę wpłat do 50\% DNB.

Do obliczonej podstawy VAT państwa członkowskie stosowały ujednolicona stawkę. W latach 2000-2006 obliczenie tej stawki było dość skomplikowane. Stanowiła ona różnicę między stawką maksymalną a tzw. stawką zamrożona. We wskazanym okresie stawka maksymalna została obniżona z 1 do $0,5 \%$. $\mathrm{Z}$ kolei stawka zamrożona była równa udziałowi tzw. rekompensaty dla Wielkiej Brytanii w sumie podstaw VAT na rzecz unijnego budżetu wszystkich państw członkowskich. Zastosowanie stawki zamrożonej wynikało z faktu, że Wielka Brytania została wyłączona z finansowania własnej rekompensaty.

Wpłaty z tytułu DNB stanowiły źródło uzupełniające zasobów własnych. Były one gromadzone w sytuacji, gdy pozostałe dochody z zasobów tradycyjnych i VAT okazały się niewystarczajace na pokrycie zaplanowanych wydatków. Wpłaty te stanowiły bezpośrednie transfery z budżetów narodowych państw członkowskich, a ich wysokość obliczana była na podstawie ujednoliconej stawki stosowanej do DNB danego państwa. Stawka ustalana była podczas corocznej procedury budżetowej i stanowiła iloraz brakujacej kwoty do zrównoważenia budżetu oraz sumy DNB państw członkowskich. Ujednolicona stawka wzrosła w badanym okresie z 0,45 do 0,62 .

Szczególną rolę w systemie zasobów własnych UE odgrywała rekompensata (rabat) dla Wielkiej Brytanii. Wielka Brytania otrzymywała rekompensatę od pozostałych państw UE z powodu zbyt dużej przewagi wpłat do budżetu ogólnego nad uzyskiwanymi z niego środkami. Tę nierównowagę Wielka Brytania odnotowuje od momentu przystapienia do Wspólnot Europejskich w 1973 r., 
a wynika ona z trzech głównych przesłanek: 1) dominującej roli unijnych wydatków na wspólną politykę rolna, podczas gdy Wielka Brytania posiada relatywnie mały sektor rolniczy i w związku z tym otrzymuje, w porównaniu z podobnymi państwami, znacznie mniej środków, 2) wysokiego udziału państw nienależących do UE (głównie państw Commonwealth) w brytyjskim imporcie produktów rolnych i nierolniczych, co powoduje, że Wielka Brytania jest drugim największym płatnikiem ceł w UE oraz 3) wysokiego udziału konsumpcji w DNB, co powoduje, że Wielka Brytania osiaga wysokie wpływy z VAT ${ }^{10}$.

Obliczenie rekompensaty jest dość zawiłe, gdyż wymaga uwzględnienia danych odnośnie do wszystkich zasobów własnych oraz wydatków. Rekompensatę dla danego roku oblicza się na podstawie danych z roku poprzedniego i uwzględnia się ją w budżecie na rok następny. W badanym okresie generalnie wynosiła ona $66 \%$ nierównowagi budżetowej Wielkiej Brytanii względem unijnego budżetu. Rekompensata była wypłacana Wielkiej Brytanii w formie redukcji wpłat z tytułu VAT i DNB, a jej koszty ponosiły pozostałe państwa członkowskie ${ }^{11}$.

Unia Europejska uzyskuje również dochody z innych, mniej lub bardziej regularnych źródeł. Obejmują one m.in. nadwyżki budżetowe z lat ubiegłych, dochody z podatku i składek od wynagrodzeń osób zatrudnionych w unijnej administracji, dochody z działalności unijnej administracji, zwroty środków związane z realizacją unijnych programów UE, czy też odsetki od zaległych płatności i grzywny.

W kolejnej perspektywie finansowej na lata 2007-2013 wprowadzono kil$\mathrm{ka}$ istotnych zmian w systemie unijnych zasobów własnych. Po pierwsze, od 2009 r. cła rolne zostały objęte wspólną taryfą celną i nie są już więcej wykazywane jako odrębne źródło dochodów. Zmiana ta wynika z reformy organizacji rynku rolnego przeprowadzonej w 2007 r., w wyniku której ujednolicono zasady funkcjonowania 24 wspólnych obszarów rolnych. Po drugie, uproszczono system obliczania wpłat z tytułu VAT przez przyjęcie stałej ujednoliconej stawki w wysokości 0,30\%. Zasady obliczenia podstawy VAT nie zmieniły się. Po trzecie, wprowadzono ulgi dla państw odnotowujących zbyt dużą nierównowagę fiskalną względem unijnego budżetu. Ulgi te zostały wkomponowane we wpłaty z tytułu VAT i DNB. W pierwszym przypadku zredukowano stawki VAT dla Austrii, Holandii, Niemiec i Szwecji, natomiast w drugim - obniżono o stała kwotę roczne wpłaty z tytułu DNB dla Holandii i Szwecji. Redukcja wpłat z tytułu DNB dla Holandii i Szwecji jest finansowana przez wszystkie państwa członkowskie, w tym Holandię i Szwecję, proporcjonalnie do udziałów w DNB. Wprowadzono również istotne zmiany w obliczaniu rekompensaty dla Wielkiej Brytanii. Zmiany wpłynęły na wielkość rekompensaty oraz sposób jej wypłacania. W tabeli 1 przedstawiono kluczowe zmiany w systemie zasobów własnych UE w latach 2000-2010, a w tabeli 2 - wielkość i strukturę dochodów budżetowych UE w tym samym okresie.

${ }_{10}$ K. Stabryła-Chudzio, Rola budżetu Unii Europejskiej w integracji społeczno-gospodarczej, Monografie: Prace Doktorskie, Nr 13, Uniwersytet Ekonomiczny w Krakowie, Kraków 2011, s. 113 .

11 Szerzej na ten temat: M. Cieślukowski, Wielokryterialna ocena systemu zasobów własnych UE, Wydawnictwo Uniwersytetu Ekonomicznego w Poznaniu, Poznań 2013, s. 121-123. 


\section{Tabela 1}

System zasobów własnych UE w latach 2000-2010

\begin{tabular}{|c|c|c|}
\hline $\begin{array}{c}\text { Zakres } \\
\text { przedmiotowy }\end{array}$ & 2000-2006 & 2007-2010 \\
\hline $\begin{array}{l}\text { Rodzaje zasobów } \\
\text { własnych }\end{array}$ & $\begin{array}{l}\text { Cła i opłaty cukrowe, Wpłaty } \\
\text { z tytułu VAT i DNB (PNB } \\
\text { w latach } 2000 \text { i 2001) }\end{array}$ & $\begin{array}{l}\text { Cła i opłaty cukrowe, Wpłaty } \\
\text { z tytułu VAT i DNB }\end{array}$ \\
\hline $\begin{array}{l}\text { Cła i opłaty } \\
\text { cukrowe }\end{array}$ & $\begin{array}{l}\text { - Koszty poboru w wysokości } 10 \\
\text { i } 25 \% \text { (od } 2001 \mathrm{r} \text {.) } \\
\text { - Odrębne zasady poboru ceł } \\
\text { rolnych i handlowych }\end{array}$ & $\begin{array}{l}\text { - Utrzymanie } 25 \% \text { kosztów poboru } \\
\text { - Objęcie ceł rolnych Wspólną } \\
\text { Taryfą Celną }\end{array}$ \\
\hline $\begin{array}{l}\text { Wpłaty z tytułu } \\
\text { VAT }\end{array}$ & $\begin{array}{l}\text { - } \text { Ograniczenie podstawy do 50\% } \\
\text { PNB (lata } 2000 \text { i 2001)/ DNB } \\
\text { (od } 2002 \text { r.) } \\
\text { - Ujednolicona stawka (różnica } \\
\text { między stawką maksymalną } \\
\text { a tzw. stawką,zamrożoną”) }\end{array}$ & $\begin{aligned}- & \text { Ograniczenie podstawy do } 50 \% \\
& \text { DNB } \\
- & \text { Ujednolicona stawka podatku } \\
& 0,30 \% \\
- & \text { Zredukowane stawki dla: Austrii } \\
& 0,225 \%, \text { Niemiec }-0,15 \%, \\
& \text { Holandii i Szwecji - } 0,10 \%\end{aligned}$ \\
\hline $\begin{array}{l}\text { Wpłaty z tytułu } \\
\text { DNB }\end{array}$ & $\begin{array}{l}\text { - Podstawa ustalana w cenach } \\
\text { rynkowych metodą ESA } 79 \\
\text { (PNB) w latach } 2000 \text { i } 2001 \\
\text { oraz ESA } 95 \text { (DNB) od } 2002 \mathrm{r} \text {. } \\
\text { - Stawka ujednolicona ustalana } \\
\text { w trakcie procedury budżetowej }\end{array}$ & $\begin{array}{l}\text { - Podstawa ustalana w cenach } \\
\text { rynkowych metoda ESA95 (DNB) } \\
\text { - } \text { Stawka ujednolicona ustalana } \\
\text { w trakcie procedury budżetowej } \\
\text { - Ulga roczna dla Holandii } \\
\text { (605 mln euro) i Szwecji } \\
\text { (150 mln euro) w cenach z } 2004 \mathrm{r} \text {. }\end{array}$ \\
\hline $\begin{array}{l}\text { Mechanizm } \\
\text { korekcyjny }\end{array}$ & $\begin{array}{l}\text { - Korekta nierównowagi tylko } \\
\text { dla Wielkiej Brytanii } \\
\text { _ } \text { Wypłata rekompensaty } \\
\text { w formie redukcji wpłaty } \\
\text { z tytułu VAT i DNB } \\
\text { - } \quad \text { Ulga w finansowaniu korekty } \\
\text { dla Niemiec do } 2 / 3 \text { pierwotnej } \\
\text { wielkości w latach } 2000 \text { i } 2001 \\
\text { - Ulgi w finansowaniu korekty } \\
\text { dla Austrii, Niemiec, Holandii } \\
\text { i Szwecji do jednej czwartej } \\
\text { pierwotnej wielkości od } \\
2002 \text { r. }\end{array}$ & $\begin{array}{l}\text { - Zmienione zasady rekompensaty } \\
\text { dla Wielkiej Brytanii od } 2009 \text { r. } \\
\text { _ } \text { Wypłata rekompensaty w formie } \\
\text { redukcji wpłaty z tytułu DNB } \\
\text { - Ulgi w finansowaniu korekty } \\
\text { dla Austrii, Niemiec, Holandii } \\
\text { i Szwecji do jednej czwartej } \\
\text { pierwotnego udziału }\end{array}$ \\
\hline Limit dochodów & $\begin{array}{l}\text { Dla płatności: } 1,27 \% \text { PNB w latach } \\
2000-2002 ; 1,24 \% \text { DNB od } 2003 \text { r.; } \\
\text { dla zobowiązań: } 1,335 \% \text { PNB } \\
\text { w latach } 2000-2002 ; 1,31 \% \text { DNB } \\
\text { od } 2003 \text { r. }\end{array}$ & $\begin{array}{l}1,24 \% \text { DNB dla płatności i } 1,31 \% \\
\text { DNB dla zobowiązań }\end{array}$ \\
\hline
\end{tabular}

Źródło: opracowano na podstawie: Council Decision of 29 September 2000 on the system of the European Communities' own resources, OJ L 253 ze zm.; Decyzja Rady z 7 czerwca 2007 r. w sprawie systemu zasobów własnych Wspólnot Europejskich, Dz. Urz. UE L 163 ze zm. 


\begin{tabular}{|c|c|c|c|c|c|c|c|c|}
\hline \multirow{12}{*}{ 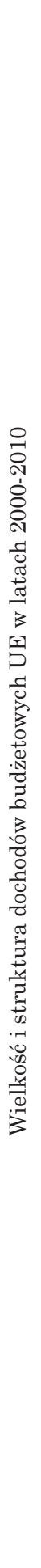 } & 을 & 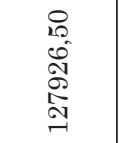 & ' & $\begin{array}{l}\stackrel{\circ}{\circ} \\
\stackrel{-}{0}\end{array}$ & 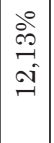 & $\begin{array}{l}\stackrel{0}{2} \\
\stackrel{1}{4} \\
0 \\
0\end{array}$ & 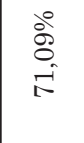 & 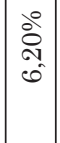 \\
\hline & ڤे & $\begin{array}{l}8 \\
8 \\
10 \\
0 \\
0 \\
0 \\
-1 \\
=\end{array}$ & ' & $\begin{array}{l}\stackrel{0}{\circ} \\
\overrightarrow{0}\end{array}$ & $\begin{array}{l}\stackrel{0}{\circ} \\
\stackrel{+}{\sim} \\
\sim \\
\sim \\
-1\end{array}$ & $\begin{array}{l}0 \\
\infty \\
\infty \\
0 \\
0 \\
-1\end{array}$ & $\begin{array}{l}\stackrel{0}{0} \\
8 \\
80\end{array}$ & $\begin{array}{l}0 \\
0 \\
0 \\
0 \\
\vdots \\
\vdots\end{array}$ \\
\hline & ֻे & 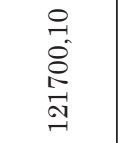 & $\begin{array}{l}\stackrel{0}{\circ} \\
\stackrel{+}{=} \\
=\end{array}$ & 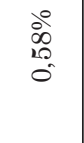 & 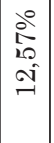 & 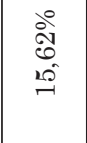 & 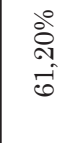 & $\begin{array}{l}\delta^{\circ} \\
\infty \\
\infty \\
\infty\end{array}$ \\
\hline & ڤ్ & 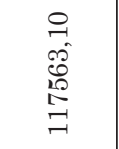 & $\begin{array}{l}\stackrel{\circ}{\circ} \\
\stackrel{-}{=}\end{array}$ & $\begin{array}{l}\text { वें } \\
\text { ठे. } \\
\text { i. }\end{array}$ & 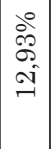 & $\begin{array}{l}0 \\
\vdots \\
10 \\
0 \\
0 \\
0\end{array}$ & $\begin{array}{l}\text { व̊ } \\
0 \\
0 \\
\text { di }\end{array}$ & $\begin{array}{c}\text { 웜 } \\
0 \\
0\end{array}$ \\
\hline & ஜ̊ํ & 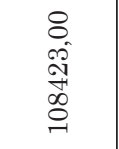 & $\begin{array}{l}\stackrel{\circ}{\circ} \\
\stackrel{-}{-}\end{array}$ & $\begin{array}{l}\stackrel{\circ}{H} \\
\stackrel{+}{0}\end{array}$ & 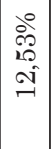 & $\begin{array}{l}\stackrel{0}{0} \\
0 \\
10 \\
0\end{array}$ & $\begin{array}{l}\otimes^{\circ} \\
0 \\
+ే\end{array}$ & $\begin{array}{l}\text { 8̊ } \\
80 \\
10 \\
10\end{array}$ \\
\hline & 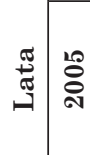 & $\begin{array}{l}8 \\
8 \\
8 \\
8 \\
\stackrel{8}{8} \\
0 \\
0\end{array}$ & $\begin{array}{l}-8 \\
\dot{o} \\
o 1 \\
-1\end{array}$ & $\begin{array}{l}\text { वे } \\
i \frac{0}{6} \\
0\end{array}$ & $\begin{array}{l}\text { ลें } \\
\text { Nิ } \\
\exists\end{array}$ & 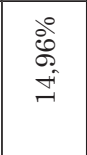 & $\begin{array}{l}\stackrel{0}{\circ} \\
\stackrel{1}{c} \\
0 \\
0\end{array}$ & \begin{tabular}{|l|}
$\stackrel{\circ}{+}$ \\
$\stackrel{+}{1}$ \\
$10^{\circ}$
\end{tabular} \\
\hline & ङ્ & $\begin{array}{l}8 \\
8 \\
\text { I } \\
10 \\
0 \\
0 \\
0 \\
-1\end{array}$ & 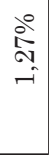 & $\begin{array}{l}\stackrel{0}{0} \\
\stackrel{\circ}{0} \\
0\end{array}$ & 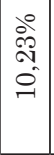 & & $\begin{array}{l}\circ 0 \\
\vdots \\
0 \\
80\end{array}$ & 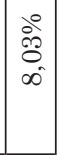 \\
\hline & ஜ̊ํํ & 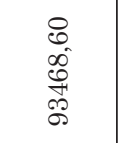 & $\begin{array}{c}\infty \\
\infty \\
0 \\
-i \\
-i\end{array}$ & $\begin{array}{l}\stackrel{0}{\overrightarrow{7}} \\
\stackrel{\forall}{0}\end{array}$ & $\begin{array}{c}\stackrel{0}{0} \\
\stackrel{2}{0} \\
\stackrel{0}{0} \\
-1\end{array}$ & $\begin{array}{l}\text { 今े } \\
\text { ลे } \\
\text { ลे }\end{array}$ & $\begin{array}{l}\stackrel{\text { Oे }}{\infty} \\
\text { \&ी }\end{array}$ & $\begin{array}{c}0 \\
\stackrel{0}{0} \\
\infty \\
0 \\
0 \\
-1\end{array}$ \\
\hline & ڤัे & 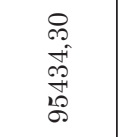 & $\begin{array}{l}0 \\
0 \\
0 \\
0\end{array}$ & $\begin{array}{l}\text { ఏें } \\
10 \\
0 \\
0\end{array}$ & 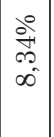 & $\begin{array}{l}\text { ذें } \\
\text { पे } \\
\text { ลे }\end{array}$ & 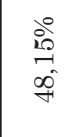 & $\mid$\begin{tabular}{c|}
$\stackrel{0}{0}$ \\
$\stackrel{+}{ \pm}$ \\
$\infty$ \\
$\infty$ \\
$\sim$
\end{tabular} \\
\hline & ఫ్రి & 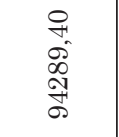 & $\begin{array}{l}0 \\
0 \\
0 \\
0 \\
-1\end{array}$ & $\begin{array}{l}\dot{0}^{0} \\
\infty \\
0 \\
0\end{array}$ & 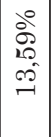 & $\begin{array}{l}\stackrel{\circ}{0} \\
\text { ஸे } \\
\text { ळे }\end{array}$ & $\begin{array}{l}\stackrel{0}{ } \\
\sigma_{0} \\
\dot{0}\end{array}$ & 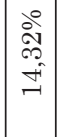 \\
\hline & ஓ્. & $\begin{array}{l}\stackrel{8}{0} \\
\stackrel{+}{1} \\
\stackrel{\text { Lิ }}{\sigma}\end{array}$ & $\begin{array}{l}\stackrel{0}{8} \\
\stackrel{0}{-1} \\
=\end{array}$ & $\begin{array}{l}\text { @े } \\
\stackrel{-1}{ت}\end{array}$ & 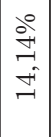 & $\begin{array}{l}\stackrel{0}{\circ} \\
\text { o } \\
\text { 心 }\end{array}$ & 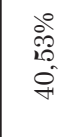 & $\begin{array}{c}20 \\
20 \\
0 \\
00^{\circ}\end{array}$ \\
\hline & $\begin{array}{l}\stackrel{8}{0} \\
\frac{0}{0} \\
\stackrel{1}{0} \\
\stackrel{0}{0}\end{array}$ & 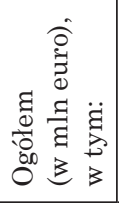 & 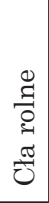 & 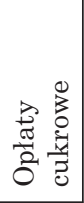 & 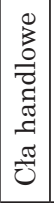 & 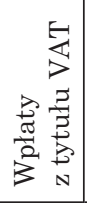 & 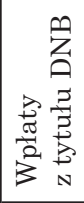 & 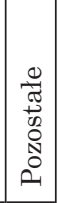 \\
\hline
\end{tabular}




\section{WSPÓŁCZYNNIK ZMIENNOŚCI}

Zgodnie z przyjętą koncepcją stabilność dochodów publicznych jest mierzona współczynnikiem zmienności, obliczanym dla określonego źródła dochodów. W artykule zastosowano klasyczny współczynnik zmienności, wyrażajacy stosunek odchylenia standardowego dochodów do średniego poziomu dochodów zgodnie ze wzorem:

$$
v=\frac{\sigma}{\mu}
$$

gdzie: $\sigma$ - oznacza odchylenie standardowe dochodów w populacji, $\mu$ - oznacza średni poziom dochodów w populacji.

W badaniach empirycznych najczęściej stosuje się estymator współczynnika zmienności (1) w postaci:

$$
V=\frac{s}{\bar{x}}
$$

gdzie: $s$ - jest odchyleniem standardowym dochodów $\mathrm{w}$ badanej próbie, a $\bar{x}$ - jest średnią dochodów w próbie.

Estymator współczynnika zmienności dany wzorem (2) jest estymatorem zgodnym, ale obciążonym współczynnika zmienności (1). W celu znalezienia nieobciążonego estymatora współczynnika zmienności (1) można obliczyć zmodyfikowany współczynnik zmienności, zgodnie ze wzorem:

$$
V_{m}=\frac{s}{\bar{x}} \cdot\left(1+\frac{1}{4 N}\right),
$$

gdzie: $s$ - jest odchyleniem standardowym dochodów $\mathrm{w}$ badanej próbie, $\bar{x}$ - jest średnią dochodów w próbie, a $N$ - wielkością próby.

Zarówno estymator dany wzorem (2), jak i (3) mogą być odpowiednim miernikiem poziomu stabilności dochodów. Jednak zgodnie z definicją za stabilne autorzy uznaja takie dochody, dla których wahania (mierzone współczynnikiem zmienności) nie przekraczają odgórnie przyjętego poziomu. Przy czym im bardziej stabilny dochód, tym mniejszej wartości współczynnika zmienności należy się spodziewać. Zatem niezwykle ważne z tego punktu widzenia jest ustalenie, jaki jest maksymalny poziom stabilności badanego dochodu. Odpowiedzią na tak postawiony problem może być ustalenie, jaka jest możliwie najmniejsza wartość współczynnika zmienności (1), od której obliczony estymator jest na przyjętym poziomie istotności większy. W ten sposób ustalona wartość wskazuje na maksymalna, możliwą do osiagnnięcia dla przyjętego poziomu istotności, ocenę stabilności dochodów. 
W celu ustalenia progu wartości współczynnika zmienności, określającego maksymalną istotną stabilność dochodów, zastosowano test statystyczny ${ }^{12}$, oparty na funkcji aproksymacyjnej $\mathrm{McKay}^{13}$. W teście tym zestaw hipotez ma postać: $\mathrm{H}_{0}: V=V_{0}$ przeciwko $\mathrm{H}_{1}: V \neq V_{0}$. W opisywanym teście statystyka testowa ma postać:

$$
V_{u}=\left(\frac{1+V_{0}^{2}}{V_{0}^{2}}\right) \cdot\left(\frac{N \cdot V^{2}}{1+V^{2}}\right),
$$

gdzie: $V_{0}$ - jest testowanym poziomem wartości progowej współczynnika zmienności, $V$ - jest estymatorem współczynnika zmienności uzyskanym na podstawie próby, a $N$ - wielkością próby.

Statystyka dana wzorem (4) ma przybliżony rozkład $\chi_{N-1}^{2}$. W celu wyznaczenia wartości progowej zastosowano wersję jednostronną testu, w której zestaw hipotez ma postać: $\mathrm{H}_{0}: V=V_{0}$ przeciwko $\mathrm{H}_{1}: V>V_{0}$ oraz procedurę obliczeniową, zgodnie z którą, metodą prób i błędów ${ }^{14}$ poszukiwano najmniejszej wartości $V_{0}$, dla której odrzucano hipotezę zerową. Ustalona w ten sposób wartość wskazuje, jaki jest górny pułap stabilności badanego dochodu (odpowiadający dolnemu pułapowi współczynnika zmienności (1)), którego nie przekroczy z zadanym prawdopodobieństwem $1-\alpha$, gdzie $\alpha$ odpowiada współczynnikowi istotności. Znaleziona w ten sposób wartość nazywana będzie $(1-\alpha) \cdot 100 \%$ progową wartością współczynnika zmienności (1).

Innym podejściem do oceny stabilności dochodu może być zbudowanie przedziału ufności dla współczynnika zmienności (1), który z zadanym prawdopodobieństwem (określonym za pomoca współczynnika ufności) zobrazuje typowy zakres, w jakim znajduje się ta wielkość. Konstrukcja przedziału ufności jest oparta na aproksymacji współczynnika zmienności (1) do rozkładu normalnego ${ }^{15}$. Górny i dolny kraniec przedziału ufności są dane wzorami:

$$
\begin{gathered}
V_{l}=\frac{V}{1+a \cdot \sqrt{1+2 V^{2}}}, \\
V_{u}=\frac{V}{1-a \cdot \sqrt{1+2 V^{2}}}, \\
a=\frac{u_{1-\alpha}}{\sqrt{2(N-1)}},
\end{gathered}
$$

${ }^{12}$ N. J. Shafer, J. A. Sullivan, A Simulation Study of a Test for the Equality of the Coefficient of Variation, „Communications in Statistics - Simulation and Computation” 15, 1986, nr 3, s. 681-695.

13 A. T. McKay, Distribution of the Coefficient of Variation and the Extended t-Distribution, „Journal of the Royal Statistical Society” 95, 1932, nr 4, s. 695-698.

${ }^{14} \mathrm{~W}$ zastosowaniach możliwe jest zastosowanie procedur symulacyjnych, pozwalajacych na znalezienie wartości progowej w sposób zautomatyzowany (dzięki solverom nieliniowym). W prezentowanym podejściu obliczenia prowadzono z dokładnością do 4 liczb znaczących i w związku z tym metoda prób i błędów nie była zbytnio uciążliwa.

15 U. Graf et al., Formeln und Tabellen der angewandten mathematischen Statistik, Springer Verlag Berlin 1987. 
gdzie: $u_{1-\alpha}-$ oznacza $(1-\alpha)$ kwantyl standardowego rozkładu normalnego, $V$ - estymator współczynnika zmienności (1), a $N$ - wielkość próby.

Obliczony przedział ufności współczynnika zmienności (1) informuje, w jakim zakresie może się zmieniać ocena stabilności badanych dochodów (na zadanym poziomie ufności). Przy czym dolna granica przedziału ufności $V_{l}$ wyznacza maksymalny poziom stabilności badanego dochodu.

Ostatnim elementem oceny stabilności dochodów jest zaproponowanie interpretacji współczynnika zmienności w kontekście oceny stabilności dochodów. Taką oceną może być podanie przedziałów liczbowych, w ramach których dochody będą oceniane jako bardziej lub mniej stabilne. Oceny stabilności dokonano na podstawie (1-a) $100 \%$ progowej wartości współczynnika zmienności zgodnie z tabelą 3 .

Tabela 3

Oceny stabilności dochodu

\begin{tabular}{|c|l|}
\hline $\begin{array}{c}\text { Wartość progowa współczynnika } \\
\text { zmienności }\end{array}$ & \multicolumn{1}{|c|}{ Ocena stabilności dochodu } \\
\hline$[0,0-0,1)$ & bardzo stabilny \\
\hline$[0,1-0,2)$ & stabilny \\
\hline$[0,2-0,3)$ & umiarkowanie stabilny \\
\hline$[0,3-0,4)$ & niestabilny \\
\hline powyżej 0,4 & bardzo niestabilny \\
\hline
\end{tabular}

Źródło: opracowanie własne.

\section{WYNIKI BADAŃ EMPIRYCZNYCH}

We wszystkich tabelach 4-9 w kolumnie zatytułowanej „współczynnik zmienności” podano wartości estymatora współczynnika zmienności obliczone zgodnie ze wzorem (2). W kolumnie „zmodyfikowany współczynnik zmienności" zamieszczono wartości estymatora nieobciążonego, danego wzorem (3). W kolumnie opisanej jako „95-procentowa progowa wartość współczynnika zmienności" podano wartości, poniżej której na podstawie statystycznego testu istotności (4) nie ma podstaw do odrzucenia hipotezy zerowej. Zgodnie z zaproponowaną terminologia jest to graniczna (progowa) wartość estymatora współczynnika zmienności, co do której możemy mieć 95\% ufności, że „prawdziwa” ocena współczynnika zmienności (1) nie będzie niższa. W ostatnich dwóch kolumnach podano odpowiednio dolną i górną granicę przedziału ufności, obliczonego dla 95-procentowego poziomu ufności z zastosowaniem wzoru (5). 
W tabeli 4 zestawiono oceny współczynnika zmienności dla poszczególnych zasobów własnych UE, obliczonych na podstawie zbiorczych danych z lat 2000-2010. Odchylenie standardowe było oszacowane na podstawie funkcji trendu liniowego każdego z zasobów osobno. Wartość średnia dotyczyła średniego dochodu w poszczególnych jego rodzajach. Jest to zatem ocena, jak bardzo były stabilne poszczególne dochody w skali całej UE w okresie jedenastu lat. Zgodnie z przyjętą terminologią im bardziej stabilny dochód, tym charakteryzuje się mniejszymi wahaniami, co pozwala na precyzyjniejszą ocenę wielkości wpływu do budżetu i tym samym precyzyjniejsze dopasowanie do zadań publicznych.

W tabelach 5-9 zamieszczono oceny współczynników zmienności obliczone na podstawie danych przekrojowych obejmujacych kraje członkowskie UE $\mathrm{w}$ każdym $\mathrm{z}$ badanych lat oddzielnie. W każdym z badanych jednorocznych okresów zebrano dane dotyczące wielkości poszczególnych dochodów i wpłat do budżetu UE z tego tytułu dla wszystkich krajów członkowskich. Następnie zbudowano funkcje regresji liniowej, wyjaśniające zależność pomiędzy wpłata do budżetu a wielkościa dochodu. Ponieważ zobowiazania krajów członkowskich są liniowo uzależnione od wielkości dochodu, teoretycznie nie powinno się obserwować różnic pomiędzy wartościami wynikającymi z funkcji regresji a faktycznymi wpływami do budżetu UE. W praktyce jednak zachodziły różne sytuacje powodujące, że wpływy do budżetu UE nie były regularne i terminowe. Powodowało to, że podczas planowania wydatków nie tylko nie można było być pewnym, jakie powinny być wpłaty (m.in. z powodu wahań koniunkturalnych), ale również nie można było być pewnym, jaka część należnego podatku faktycznie zostanie wpłacona. Im większa skala różnic pomiędzy faktycznymi a należnymi wpływami, tym mniej stabilny był dany zasób. Pomiaru stopnia niestabilności dokonywano na podstawie współczynnika zmienności obliczonego dla każdego zasobu w każdym roku oddzielnie.

$\mathrm{Na}$ podstawie obliczonych w tabeli 4 estymatorów można stwierdzić, że (por. tabela 3) dochody z tytułu DNB były w badanym okresie bardzo stabilne, wpływy z VAT można ocenić generalnie jako stabilne lub umiarkowanie stabilne, cła handlowe i cła rolne również okazały się stabilne natomiast dochody z tytułu opłat cukrowych są bardzo niestabilne. Dochody z pozostałych źródeł były niestabilne lub bardzo niestabilne.

Bardziej szczegółowa analiza oceny stabilności zostanie przedstawiona na przykładzie dochodów z tytułu VAT. Tradycyjny estymator współczynnika zmienności, kształtuje się na poziomie 0,2234. Natomiast nieobciążony estymator tego współczynnika przyjmuje wartość 0,2031 . Na podstawie obu tych wartości VAT można by ocenić jako umiarkowanie stabilne źródło dochodu. Jednakże oszacowanie wartości estymatora wiąże się z możliwościa popełnienia błędu wynikającego z niedoskonałości narzędzi statystycznych. W przypadku podanych estymatorów brakuje jednak informacji o możliwej skali popełnianego błędu. Wartość progowa dla dochodów z tytułu VAT została oszacowana na poziomie 0,1714 przy założeniu $95 \%$ poziomu ufności. Oznacza to mniej więcej tyle, że z 95-procentową pewnością dochody z tytułu VAT 
będą co najwyżej stabilne (por. tabela 3). Przy czym istnieje możliwość, że ich ocena stabilności spadnie np. do poziomu umiarkowana stabilność, lub niżej. Prawdopodobieństwo tego, że dochody z tytułu VAT były bardzo stabilne jest niewielkie i mieści się w przyjętym 5-procentowym marginesie dopuszczalnego błędu. Oszacowany przedział ufności współczynnika zmienności wynosi $(0,1612 ; 0,3636)$. Pozwala to na sformułowanie wniosku, że z 95-procentowa ufnością dochody z tytułu VAT cechują się oceną stabilności od stabilny, przez umiarkowanie stabilny, do niestabilny.

Tabela 4

Ocena stabilności całego systemu dochodów w latach 2000-2010

\begin{tabular}{|l|c|c|c|c|c|}
\hline \multicolumn{1}{|c|}{$\begin{array}{c}\text { Rodzaj } \\
\text { dochodu }\end{array}$} & $\begin{array}{c}\text { Współczynnik } \\
\text { zmienności }\end{array}$ & $\begin{array}{c}\text { Zmodyfikowany } \\
\text { współczynnik } \\
\text { zmienności }\end{array}$ & $\begin{array}{c}\text { 95-procentowa } \\
\text { progowa wartość } \\
\text { współczynnik } \\
\text { zmienności }\end{array}$ & \multicolumn{2}{|c|}{$\begin{array}{c}\text { 95-procentowy } \\
\text { przedział ufności }\end{array}$} \\
\hline DNB & 0,0851 & 0,0774 & 0,0659 & 0,0621 & 0,1353 \\
\hline VAT & 0,2234 & 0,2031 & 0,1714 & 0,1612 & 0,3636 \\
\hline $\begin{array}{l}\text { Cła } \\
\text { handlowe }\end{array}$ & 0,1603 & 0,1458 & 0,1236 & 0,1164 & 0,2574 \\
\hline Cła rolne & 0,1422 & 0,1293 & 0,1097 & 0,1034 & 0,2276 \\
\hline $\begin{array}{l}\text { Opłaty } \\
\text { cukrowe }\end{array}$ & 0,5742 & 0,5220 & 0,4184 & 0,3896 & 1,0912 \\
\hline Pozostałe & 0,4166 & 0,3787 & 0,3121 & 0,2920 & 0,7269 \\
\hline
\end{tabular}

Źródło: obliczenia własne.

Z przedstawionego przykładu wynika, że progowa wartość współczynnika zmienności dostarcza najbardziej precyzyjna informacje na temat oceny stabilności. Dlatego tė̇ w sytuacjach, kiedy różne estymatory będą sugerowały różne oceny stabilności, rozstrzygająca będzie ocena na podstawie wartości progowej. Dla przykładu dochody z tytułu VAT można ocenić jako stabilne w badanym okresie.

Dochody UE z tytułu DNB w większości przypadków były niestabilne (tabela 5). Największą stabilność, ocenianą jako bardzo stabilne, uzyskano w 2001 r. W 2010 r. można te dochody ocenić jako stabilne natomiast w 2000 jako umiarkowanie stabilne. W pozostałych przypadkach współczynnik zmienności przyjmował zdecydowanie wyższe wartości.

Wpływy z tytułu VAT (tabela 6) w latach 2000-2010 okazały się niestabilne lub bardzo niestabilne. W podobny sposób kształtowały się również cła rolne (tabela 8). Na ich tle nieco lepiej wygląda ocena dotycząca stabilności dochodów z tytułu ceł handlowych (tabela 7 ). $\mathrm{Z}$ reguły były one umiarkowanie stabilne, a w latach 2000 i 2001 - stabilne. 


\section{Tabela 5}

Stabilność dochodów z tytułu DNB w latach 2000-2010 (ujęcie przekrojowe)

\begin{tabular}{|c|c|c|c|c|c|}
\hline Lata & $\begin{array}{c}\text { Współczynnik } \\
\text { zmienności }\end{array}$ & $\begin{array}{c}\text { Zmodyfikowany } \\
\text { współczynnik } \\
\text { zmienności }\end{array}$ & $\begin{array}{c}\text { 95-procentowa } \\
\text { progowa wartość } \\
\text { współczynnik } \\
\text { zmienności }\end{array}$ & \multicolumn{2}{|c|}{$\begin{array}{c}\text { 95-procentowy } \\
\text { przedział ufności }\end{array}$} \\
\hline 2000 & 0,3637 & 0,3394 & 0,2826 & 0,2695 & 0,5591 \\
\hline 2001 & 0,0696 & 0,0650 & 0,0553 & 0,0531 & 0,1012 \\
\hline 2002 & 0,4438 & 0,4142 & 0,3410 & 0,3247 & 0,7011 \\
\hline 2003 & 0,4789 & 0,4469 & 0,3660 & 0,3482 & 0,7667 \\
\hline 2004 & 0,4204 & 0,4036 & 0,3390 & 0,3294 & 0,5809 \\
\hline 2005 & 0,4110 & 0,3946 & 0,3318 & 0,3225 & 0,5666 \\
\hline 2006 & 0,4091 & 0,3928 & 0,3304 & 0,3211 & 0,5637 \\
\hline 2007 & 0,3808 & 0,3667 & 0,3105 & 0,3025 & 0,5140 \\
\hline 2008 & 0,4891 & 0,4710 & 0,3934 & 0,3829 & 0,6768 \\
\hline 2009 & 0,4772 & 0,4595 & 0,3844 & 0,3742 & 0,6583 \\
\hline 2010 & 0,2192 & 0,2111 & 0,1813 & 0,1769 & 0,2880 \\
\hline
\end{tabular}

Źródło: obliczenia własne.

Tabela 6

Stabilność dochodów z tytułu VAT w latach 2000-2010 (ujęcie przekrojowe)

\begin{tabular}{|c|c|c|c|c|c|}
\hline Lata & $\begin{array}{c}\text { Współczynnik } \\
\text { zmienności }\end{array}$ & $\begin{array}{c}\text { Zmodyfikowany } \\
\text { współczynnik } \\
\text { zmienności }\end{array}$ & $\begin{array}{c}\text { 95-procentowa } \\
\text { progowa wartość } \\
\text { współczynnik } \\
\text { zmienności }\end{array}$ & \multicolumn{2}{|c|}{$\begin{array}{c}\text { 95-procentowy } \\
\text { przedział ufności }\end{array}$} \\
\hline 2000 & 0,5413 & 0,5052 & 0,4093 & 0,3890 & 0,8895 \\
\hline 2001 & 0,5027 & 0,4692 & 0,3826 & 0,3639 & 0,8126 \\
\hline 2002 & 0,4240 & 0,3957 & 0,3268 & 0,3112 & 0,6650 \\
\hline 2003 & 0,4969 & 0,4638 & 0,3787 & 0,3601 & 0,8014 \\
\hline 2004 & 0,5378 & 0,5163 & 0,4266 & 0,4142 & 0,7664 \\
\hline 2005 & 0,4971 & 0,4772 & 0,3967 & 0,3853 & 0,7003 \\
\hline 2006 & 0,5275 & 0,5064 & 0,4191 & 0,4069 & 0,7495 \\
\hline 2007 & 0,4657 & 0,4484 & 0,3757 & 0,3658 & 0,6406 \\
\hline 2008 & 0,4511 & 0,4344 & 0,3647 & 0,3550 & 0,6184 \\
\hline 2009 & 0,6071 & 0,5846 & 0,4795 & 0,4668 & 0,8681 \\
\hline 2010 & 0,4240 & 0,4083 & 0,3440 & 0,3349 & 0,5777 \\
\hline
\end{tabular}

Źródło: obliczenia własne. 


\section{Tabela 7}

Stabilność dochodów z tytułu ceł handlowych (bez ceł rolnych) w latach 2000-2010 (ujęcie przekrojowe)

\begin{tabular}{|c|c|c|c|c|c|}
\hline Lata & $\begin{array}{c}\text { Współczynnik } \\
\text { zmienności }\end{array}$ & $\begin{array}{c}\text { Zmodyfikowany } \\
\text { współczynnik } \\
\text { zmienności } \\
\text { progowa wartość } \\
\text { współczynnika } \\
\text { zmienności }\end{array}$ & \multicolumn{2}{|c|}{$\begin{array}{c}\text { 95-procentowy } \\
\text { przedział ufności }\end{array}$} \\
\hline 2000 & 0,1947 & 0,1817 & 0,1539 & 0,1473 & 0,2874 \\
\hline 2001 & 0,2221 & 0,2073 & 0,1751 & 0,1675 & 0,3294 \\
\hline 2002 & 0,2874 & 0,2682 & 0,2253 & 0,2152 & 0,4325 \\
\hline 2003 & 0,2889 & 0,2696 & 0,2264 & 0,2163 & 0,4349 \\
\hline 2004 & 0,3786 & 0,3635 & 0,3069 & 0,2983 & 0,5182 \\
\hline 2005 & 0,3545 & 0,3403 & 0,2881 & 0,2801 & 0,4827 \\
\hline 2006 & 0,3186 & 0,3059 & 0,2599 & 0,2528 & 0,4308 \\
\hline 2007 & 0,3191 & 0,3073 & 0,2618 & 0,2553 & 0,4257 \\
\hline 2008 & 0,3499 & 0,3369 & 0,2862 & 0,2789 & 0,4693 \\
\hline 2009 & 0,2743 & 0,2642 & 0,2260 & 0,2204 & 0,3632 \\
\hline 2010 & 0,2914 & 0,2806 & 0,2397 & 0,2338 & 0,3869 \\
\hline
\end{tabular}

Źródło: obliczenia własne.

Tabela 8

Stabilność dochodów z tytułu ceł rolnych w latach 2000-2008 (ujęcie przekrojowe)

\begin{tabular}{|c|c|c|c|c|c|}
\hline Lata & $\begin{array}{c}\text { Współczynnik } \\
\text { zmienności }\end{array}$ & $\begin{array}{c}\text { Zmodyfikowany } \\
\text { współczynnik } \\
\text { zmienności }\end{array}$ & $\begin{array}{c}\text { 95-procentowa } \\
\text { progowa wartośc } \\
\text { współczynnika } \\
\text { zmienności }\end{array}$ & \multicolumn{2}{|c|}{$\begin{array}{c}\text { 95-procentowy } \\
\text { przedział ufności }\end{array}$} \\
\hline 2000 & 0,8966 & 0,8368 & 0,6270 & 0,5969 & 1,8002 \\
\hline 2001 & 0,9182 & 0,8570 & 0,6386 & 0,6083 & 1,8718 \\
\hline 2002 & 0,9627 & 0,8985 & 0,6618 & 0,6312 & 2,0273 \\
\hline 2003 & 0,7688 & 0,7176 & 0,5546 & 0,5269 & 1,4216 \\
\hline 2004 & 0,8223 & 0,7894 & 0,6188 & 0,6028 & 1,2932 \\
\hline 2005 & 0,8835 & 0,8481 & 0,6561 & 0,6402 & 1,4248 \\
\hline 2006 & 0,9934 & 0,9536 & 0,7193 & 0,7048 & 1,6819 \\
\hline 2007 & 1,0701 & 1,0305 & 0,7674 & 0,7569 & 1,8253 \\
\hline 2008 & 1,0829 & 1,0428 & 0,7742 & 0,7641 & 1,8582 \\
\hline
\end{tabular}

Źródło: obliczenia własne. 
Szerszego opisu wymaga ocena stabilności dochodów z tytułu opłat cukrowych. W przypadku tego zasobu zdarzało się, że część opłat była zwracana z powodu nadpłaty. W takim przypadku mogła pojawić się bliska zeru lub ujemna wartość średniego dochodu. Efektem jest niewiarygodna ocena (znacznie zawyżona lub ujemna) współczynnika zmienności. Tym samym problematycznym może stać się zastosowanie proponowanej miary do oceny stabilności zasobu własnego. W latach 2006-2010 można zaobserwować różnego rodzaju problemy z oceną współczynnika zmienności. W 2007 i 2009 r. nie było możliwe obliczenie wartości progowej z uwagi na ujemne wartości współczynnika zmienności. W latach 2006, 2007 i 2009 aproksymacja przedziału ufności nie jest poprawna z powodu ekstremalnie wysokiej (lub małej) oceny współczynnika zmienności. Ale pomimo tych problemów dochód w tych latach z wyłączeniem roku 2008 można ocenić jako niestabilny.

Tabela 9

Stabilność dochodów z tytułu opłat cukrowych w latach 2000-2010 (ujęcie przekrojowe)

\begin{tabular}{|c|c|c|c|c|c|}
\hline Lata & $\begin{array}{c}\text { Współczynnik } \\
\text { zmienności }\end{array}$ & $\begin{array}{c}\text { Zmodyfikowany } \\
\text { współczynnik } \\
\text { zmienności }\end{array}$ & $\begin{array}{c}\text { 95-procentowa } \\
\text { progowa wartość } \\
\text { współczynnika } \\
\text { zmienności }\end{array}$ & \multicolumn{2}{|c|}{$\begin{array}{c}\text { 95-procentowy } \\
\text { przedział ufności }\end{array}$} \\
\hline 2000 & 0,2187 & 0,2041 & 0,1725 & 0,1650 & 0,3241 \\
\hline 2001 & 0,2193 & 0,2047 & 0,1729 & 0,1654 & 0,3251 \\
\hline 2002 & 0,4698 & 0,4384 & 0,3595 & 0,3421 & 0,7494 \\
\hline 2003 & 0,4426 & 0,4131 & 0,3402 & 0,3238 & 0,6989 \\
\hline 2004 & 0,8485 & 0,8146 & 0,6350 & 0,6190 & 1,3487 \\
\hline 2005 & 0,4907 & 0,4711 & 0,3920 & 0,3807 & 0,6902 \\
\hline 2006 & 5,2793 & 5,0681 & 1,4010 & 1,8933 & $-6,6964$ \\
\hline 2007 & $-2,0838$ & $-2,0066$ & $\mathrm{x}$ & $-1,2187$ & $-7,1816$ \\
\hline 2008 & 0,3278 & 0,3157 & 0,2687 & 0,2619 & 0,4379 \\
\hline 2009 & $-6,5756$ & $-6,3320$ & $\mathrm{x}$ & $-2,0985$ & 5,8017 \\
\hline 2010 & 1,0751 & 1,0353 & 0,7701 & 0,7598 & 1,8382 \\
\hline
\end{tabular}

$\mathrm{x}-\mathrm{z}$ uwagi na ujemną wartość oczekiwana, nie zostały spełnione założenia testu statystycznego Źródło: obliczenia własne.

\section{WNIOSKI}

Ocena stabilności systemu dochodów publicznych jest istotna z punktu widzenia prowadzenia krótko- i długoterminowej polityki finansowej. Brak powszechnie przyjętych mierników tego zjawiska skłonił autorów do zaproponowania metody pomiaru stabilności za pomocą współczynnika zmienności. Bardziej zaawansowana metoda obliczania tego miernika pozwala na sta- 
tystyczną ocenę istotności tego, w jakiej mierze badany zasób jest stabilny. Zaproponowana w artykule opisowa klasyfikacja stabilności jest przykładem opisu skwantyfikowanej oceny stopnia stabilności zasobu.

Badania empiryczne, będące przykładem zastosowania proponowanego podejścia, dotyczyły systemu zasobów własnych UE. Badania przeprowadzono w dwóch kierunkach, przyjmujac (w bardziej zaawansowanej propozycji pomiaru) 95-procentowy poziom ufności. W pierwszym podejściu zbadano długookresową stabilność systemu na podstawie trendów poszczególnych zasobów w latach 2000-2010, w drugim - krótkookresową stabilność, obejmująca jeden rok, za pomoca modelu przekrojowej regresji liniowej. Zastosowano modele liniowe z uwagi na wprost proporcjonalną zależność pomiędzy wielkością DNB państwa członkowskiego UE a wielkościa uiszczanych do unijnego budżetu wpłat z danego tytułu. Wyniki empiryczne potwierdzaja przypuszczenia dotyczące stabilności zasobów własnych. W przypadku DNB zaobserwowano długookresową stabilność (ocena bardzo stabilny), ale w każdym z poszczególnych lat zasób ten okazał się mniej stabilny (najczęstsza ocena to niestabilny). Sytuację taką można nazwać strukturalną niestabilnościa, gdyż problemy dotyczące zapewnienia stabilności dochodów powtarzały się co rok i ich charakter wskazuje na trwałe występowanie problemów z zapewnieniem stabilności dochodów. W podobny sposób kształtowały się wpływy z tytułu VAT, z tym że były one generalnie nieco mniej stabilne. W przypadku VAT warto również podkreślić, że zmiany w konstrukcji zasobu wprowadzone od 2007 r. nie zmieniły w istotny sposób oceny stabilności. Cła handlowe (bez ceł rolnych) były stabilnym lub umiarkowanie stabilnym zasobem zarówno w ujęciu krótko-, jak i długookresowym. Jednocześnie zmiany w konstrukcji tego zasobu nie wpłynęły w istotny sposób na ocenę jego stabilności. Natomiast cła rolne były stabilne w badaniu długookresowym i bardzo niestabilne w badaniu krótkookresowym. Opłaty cukrowe, z wyjątkiem lat 2000 i 2001, okazały się zasobem niestabilnym lub bardzo niestabilnym. Pozostałe dochody budżetu UE były generalnie niestabilne w ujęciu długookresowym.

Z przeprowadzonej analizy wynika, że zaproponowana metoda pomiaru i oceny pozwala w sposób transparentny opisać i porównać stabilność różnych dochodów publicznych. Może ona również być stosowana do porównania stabilności dochodów na różnych szczeblach władzy publicznej. Warto podkreślić, że na ocenę tę nie wpływają wahania koniunkturalne.

dr Przemystaw Garsztka

Uniwersytet Ekonomiczny w Poznaniu

przemyslaw.garsztka@ue.poznan.pl

dr Maciej Cieślukowski

Uniwersytet Ekonomiczny w Poznaniu

m.cieslukowski@ue.poznan.pl 


\section{ASSESSMENT OF THE STABILITY OF PUBLIC REVENUES ON THE EXAMPLE OF EU'S OWN RESOURCES BETWEEN 2000 AND 2010}

\section{Summary}

Stable public revenues provide funding for the implementation of public tasks and ensure safety of broadly understood public finances. The concept of sustainability of public revenues, however, has not been clearly defined. The article explains in more detail the concept of sustainability of public revenues and suggests methods for measuring the stability of so-called coefficient of variation. The analysis was conducted on the example of the European Union's own resources available in the years 2000-2010. Empirical studies were carried out for various types of revenues and examined from various angles, which allowed to obtain differenciated results. The proposed coefficient of variation can transparently describe and compare the stability of various public revenues, regardless of the economic cycle. It can also be used to compare the stability of revenues at various levels of public authority. 
Copyright of Journal of Law, Economics and Sociology is the property of Faculty of Law and Administration of Adam Mickiewicz University in Poznan and its content may not be copied or emailed to multiple sites or posted to a listserv without the copyright holder's express written permission. However, users may print, download, or email articles for individual use.

Właścicielem praw autorskich do „Ruchu Prawniczego, Ekonomicznego i Socjologicznego” jest Wydział Prawa i Administracji Uniwersytetu im. Adama Mickiewicza w Poznaniu. Zawartość czasopisma nie może być kopiowana, przesyłana do innych stron internetowych bądź zamieszczana na blogach bez pisemnej zgody wydawcy. Niemniej artykuły można drukować, kopiować lub przesyłać w formie elektronicznej na własny użytek. 